\title{
Investigating the effects of phytohormones on growth and $\beta$-carotene production in a naturally isolates stain of Dunaliella salina
}

\author{
Pegah Mousavi ${ }^{1}$, Mohammad Hossein Morowvat ${ }^{1}$, Nima Montazeri-Najafabady ${ }^{2}$, Zohreh Abolhassanzadeh ${ }^{1}$, \\ Abdolali Mohagheghzadeh ${ }^{1,3}$, Mehrdad Hamidi $^{4}$, Ali Niazi ${ }^{5}$, Younes Ghasemi ${ }^{1,2^{*}}$ \\ ${ }^{1}$ Pharmaceutical Sciences Research Center, School of Pharmacy, Shiraz University of Medical Sciences, Shiraz, Iran. ${ }^{2}$ Department of Pharmaceutical \\ Biotechnology, School of Pharmacy, Shiraz University of Medical Sciences, P.O. Box 71468-64685, Shiraz, Iran. ${ }^{3}$ Department of Traditional Pharmacy, \\ School of Pharmacy, Shiraz University of Medical Sciences, P.O. Box 71468-64685, Shiraz, Iran. ${ }^{4}$ Department of Pharmaceutics, School of Pharmacy, \\ Zanjan University of Medical Sciences, P.O. Box 45139-56184, Zanjan, Iran. ${ }^{5}$ Institute of Biotechnology, Shiraz University, Shiraz, Iran.
}

\begin{tabular}{l} 
ARTICLE INFO \\
\hline Article history: \\
Received on: $21 / 05 / 2016$ \\
Revised on: $16 / 06 / 2016$ \\
Accepted on: 06/07/2016 \\
Available online: $30 / 08 / 2016$ \\
\hline Key words: \\
$\begin{array}{l}\text { } \text {-carotene, Dunaliella salina, } \\
\text { Growth rate, Plant growth } \\
\text { regulators. }\end{array}$ \\
\hline
\end{tabular}

\section{INTRODUCTION}

Algae constitute a vast part of many ecosystems such as sea, fresh water, desert sands, and snowy or icy regions. They provide more than $50 \%$ of total initiatory productivity at the base of world food chain (Ghasemi et al., 2011a). The algae of the genus Dunaliella especially D. salina and D. tertiolecta are among the microalgae most studied for mass culture. Dunaliella spp. are grown as a food source in aquaculture and D. salina is the richest algal source of glycerol and $\beta$-carotene. $\beta$-carotene and other carotenoids are naturally occurring pigments that have important biological properties and nutritional (Emeish, 2012, Rasoul-Amini et al., 2014). Microalgal culture is one of the

\footnotetext{
* Corresponding Author

Younes Ghasemi, Pharmaceutical Sciences Research Center, Shiraz University of Medical Sciences, P.O. Box 71345-1583,

Shiraz, Iran.Email: ghasemiy@sums.ac.ir
}

modern concepts in biotechnology (Rasoul-Amini et al., 2014, Venkatesan et al., 2013, Yazdi et al., 2005). Growing interest in carotenoid production by microalgae especially $D$. salina is due to the crucial commercial applications of these natural compounds and to the market demand of carotenoids, especially for nutritional and pharmaceutical applications (Guedes et al., 2011). Carotenoids have conventionally been industrialized as food additives including antioxidants, colorants and vitamins (Ye et al., 2008). Their protective capability against oxygen free radicals appears to be responsible for the therapeutic applications of carotenoids as anticancer agents, immune system stimulators and degenerative diseases preventives as claimed by several researchers (Salguero et al., 2003). $\beta$-carotene plays an important role in the human body because of its pro-vitamin A activity. Carotenoids are also powerful antioxidants, scavenging potential hurtful oxy radicals, which are generally associated with the induction of particular cancers. Therefore, carotenoids, and mostly $\beta$-carotene are extensively used by pharmaceutical, food, and cosmetic industries. 
Rising demands for $\beta$-carotene, mainly natural $\beta$-carotene, has brought about growing interest in $\beta$-carotene extraction from diverse natural sources (Cardoso et al., 2012). The halo-tolerant microalgae Dunaliella salina, produces the highest concentrations of $\beta$-carotene, obtaining levels of up to $100 \mathrm{~g} \mathrm{Kg}^{-1}$ on dry weight basis (Ben-Amotz et al., 1988).

D. salina can fabricate and accumulate $\beta$-carotene compound in response to stress conditions (Lamers et al., 2008). Industrial production of $\beta$-carotene from $D$. salina occurs in two steps. The first step involves cell growth, followed by a second step in which cells are stressed. Due to stress, $\beta$-carotene accumulates, then the cells are harvested and $\beta$-carotene extracted and purified (Hejazi et al., 2004). Several methods have been suggested to improve the productivity of fermentation systems (Ghasemi et al., 2012; Hejazi et al., 2004) such as increasing salinity (Chen et al. 2009), light/dark cycles and temperature (Dipak and Lele, 2005).

Genetic elements, membrane, and enzymatic pathways inside the organism modulate the life conditions of a single cell organism. Regarding the evolution hypothesis about the eukaryotic cell derivation, the plastid apparatus is derived from a prokaryotic photosynthesizing organism. In addition, synthesis and function of phytohormones is related to plastids. Therefore, it is suggested that phytohormones could play their plant like modulatory roles in algae (Tarakhovskaya et al., 2007). D. salina is not a plant but somehow it is similar to plant cells. Gibberellins (GAs) belong to a big group of plant hormones in throughout the life cycle of plants involved in different responses. The general role of GAs could be summarized in germination stimulation, flowering time regulation and cell expansion. They were isolated from Giberella fungus but found afterwards in various bacteria and many plant species including unicellular and multicellular algae (Sabovljević et al., 2010).

IAA belongs to auxins, which exert a strong influence over processes such as cell growth expansion and initiation of cell division in plant cells. KN and BAP are the members of cytokinin class which stimulate cell division in plant cells. On the other hand, auxins affect DNA replication, whereas cytokines seem to exert some events leading to mitosis and cytokinesis. Gibberellic acid, belonging to the gibberellins class, increase the cell division in plant cells (Gaspar et al., 1996, Gross, 1975). In one study, the relationship between abscisic acid (a plant growth regulator) production and $\beta$-carotene accumulation was inspected in saltstressed cells of $D$. salina and a likely role of abscisic acid as a regulator of carotenogenesis in the cells of $D$. salina was evaluated (Cowan and Rose, 1991).

Therefore, it seems that some other plant growth regulators could be as a kind of stress. It was supposed these plant growth regulators could affect unicellular eukaryote $D$. salina in a way that they affect plant cells (Hejazi et al., 2004). To our best knowledge, this study is one of the few attempts to disclose the role of BAP, Benzyl amino purine; 2, 4-D, 2,4-Dichlorophenoxy acetic acid; $\mathrm{GA}_{3}$, Gibberellic acid; KN, Kinetin; SA, salicylic acid; DAP, $6 \gamma, \gamma$-Dimethylallyl aminopurine on $\beta$-carotene production by $D$. salina, which are able to enhance carotenoid production in that microalga.

\section{MATERIALS AND METHODS}

\section{Organism and culture conditions}

D. salina was isolated from water samples collected from Maharlu Salt Lake located $30 \mathrm{~km}$ southeast of Shiraz (latitude 29.26 N, longitude 52.48 E), Iran. Single colonies were derived from individual cells by repeated sub-culturing on agar plates as described elsewhere (Ghasemi et al., 2008; Powtongsook et al., 1995). Each colony was transferred to liquid nutrient medium. Purified D. salina was cultured in modified Johnson medium.

\section{Identification of microalga}

Identification of the isolated unicellular green alga was done using morphological studies and taxonomical approaches (Polle et al., 2008). Besides, the 18S rRNA sequence of the isolated strain was studied.

\section{$18 S$ ribosomal RNA sequencing}

DNA content was first extracted from the microalga and then PCR was applied using two set primers. Sequences were amplified using the primers 5'-GTCAGAGGTGAAATTCTTG GATTTA-3' and 5'-AGGGCAGGGACGTAATCAACG-3', which amplify a $\sim 700$-bp region of the $18 \mathrm{~S}$ rRNA gene. To extract of DNA from the D. salina, a fresh biomass was obtained by centrifuging at $12000 \mathrm{rpm}$. Cell lysis was done with incubation at $96^{\circ}$ tor $5 \mathrm{~min}$ and centrifugation at $12000 \mathrm{rpm}$ after washing of biomass two times with distilled water. The supernatant used as a template for PCR. The applied PCR condition has been described before (Ghasemi et al., 2011b). PCR products were electrophoresed in a $1 \%(\mathrm{w} / \mathrm{v})$ agarose gel using TBE buffer containing $1 \mu \mathrm{g} / \mathrm{mL}$ ethidium bromide. A single $\sim 700$-bp band of DNA was cut and extracted from the gel using the Core Bio Gel Extraction Kit. The sequence was determined by the CinnaGen Company with the primers. Sequence similarity searches were done with BLAST through the NCBI database.

D. salina was cultivated in Johnson culture medium supplemented with different growth regulators with various concentrations $(0.01,0.1$ and $1 \mu \mathrm{M})$ of each kinetin $(\mathrm{KN})$, indole3 -acetic acid (IAA), benzyl amino purine (BAP), $6 \gamma, \gamma$ Dimethylallylaminopurine (DAP), salicylic acid (SA) and gibberellic acid $\left(\mathrm{GA}_{3}\right)$, respectively. All the media contained $12 \%$ $\mathrm{NaCl}$ and the $\mathrm{pH}$ of the medium was adjusted to 7.5 before autoclaving. Cells were grown in $100 \mathrm{~mL}$ of culture medium in $250 \mathrm{~mL}$ Erlenmeyer flasks at $25 \pm 2{ }^{\circ} \mathrm{C}$ on a rotary shaker $(70 \mathrm{rpm}$ ) under continuous illumination of $60 \mu \mathrm{Em}^{-2} \mathrm{~s}^{-1}$. Each Erlenmeyer flask was incubated with $1 \mathrm{~mL}$ of 3 -week old pure culture containing $5 \times 10^{5}$ cells $\mathrm{mL}^{-1}$.

The evolutionary history was inferred using the Minimum Evolution method (Saitou and Nei, 1987). The bootstrap consensus tree inferred from 1000 replicates was taken to represent the evolutionary history of the taxa analyzed. Branches 
corresponding to partitions reproduced in less than $50 \%$ bootstrap replicates are collapsed. The percentage of replicate trees in which the associated taxa clustered together in the bootstrap test (1000 replicates) are shown next to the branches (Felsenstein, 1985). The evolutionary distances were computed using the Maximum Composite Likelihood method is in the units of the number of base substitutions per site (Tamura et al., 2004). The ME tree was searched using the Close-Neighbor-Interchange (CNI) algorithm [4] at a search level of 3. The Neighbor-joining algorithm (Tamura et al., 2007) was used to generate the initial tree. All positions containing gaps and missing data were eliminated from the dataset (Complete deletion option). There were a total of 333 positions in the final dataset. Phylogenetic analyses were conducted in MEGA4 (Tamura et al., 2007).

\section{Cell counting}

The cell number was determined daily by direct counting, using a light microscope (magnification $\times 10$ ) with a 0.1 $\mathrm{mm}$ deep counting chamber (Neubauer improved).

\section{$\beta$-carotene extraction}

Prior to $\beta$-carotene analysis, the sample preparation was carried out as follows. After 5, 10, 15, 20, 25 days of incubation, one $\mathrm{mL}$ sample was taken from the culture while being mixed thoroughly. After $5 \mathrm{~min}$. centrifugation at $3000 \mathrm{rpm}$, the supernatant was discarded. Then, $3 \mathrm{~mL}$ of $\mathrm{n}$-hexane: ethanol (1:2) was added to the remaining pellet and each sample was mixed by vortex for 1-2 minutes to reach a complete extraction followed by adding $2 \mathrm{~mL}$ distilled water and $4 \mathrm{~mL}$-hexane respectively. The samples were centrifuged again for 5 minutes at $3000 \mathrm{rpm}$ for separation of the remaining pellet colorless from the solvent phase. The extracted pigments were solved in n-hexane phase. Finally, the extracted pigments in the solvent phase were quantified by spectrophotometer (Eijckelhoff and Dekker, 1997).

\section{$\beta$-carotene assay}

Beta-carotene content was measured at $450 \mathrm{~nm}$ using a UV/Visible spectrophotometer (PG instrument Ltd.). The amount of $\beta$-carotene extracted in $n$-hexane was determined using spectrophotometry method using the following equation (1):

$$
ß-\text { carotene }(\mu \mathrm{g} / \mathrm{mL})=25.2 \times \mathrm{A} 450(\mathrm{Eq} .1)
$$

\section{Data analysis}

The alignment tool of the MEGA software package was used for aligning $18 \mathrm{~S}$ ribosomal RNA sequenceswith previously deposited sequences in the NCBI database. A dendrogram was constructed using then different methods integrated in the software, including Maximum Composite Likelihood method, maximum parsimony, and neighbor-joining procedures (Tamura et al., 2007). Three independent experiment run in triplicate each and data were statistically analyzed using the SPSS version 16.0, Tukey method and $95 \%$ confidence and were reported as means \pm SE ( $p<0.05$ was considered as significant).

\section{RESULTS}

D. salina isolated from Maharlu Salt Lake in Shiraz, Iran was confirmed by morphological property and PCR amplification of $18 \mathrm{~S}$ rRNA partial sequence. The partial sequence of the $18 \mathrm{~S}$ rRNA was deposited in NCBI as EF682841.2 (Fig. 1).

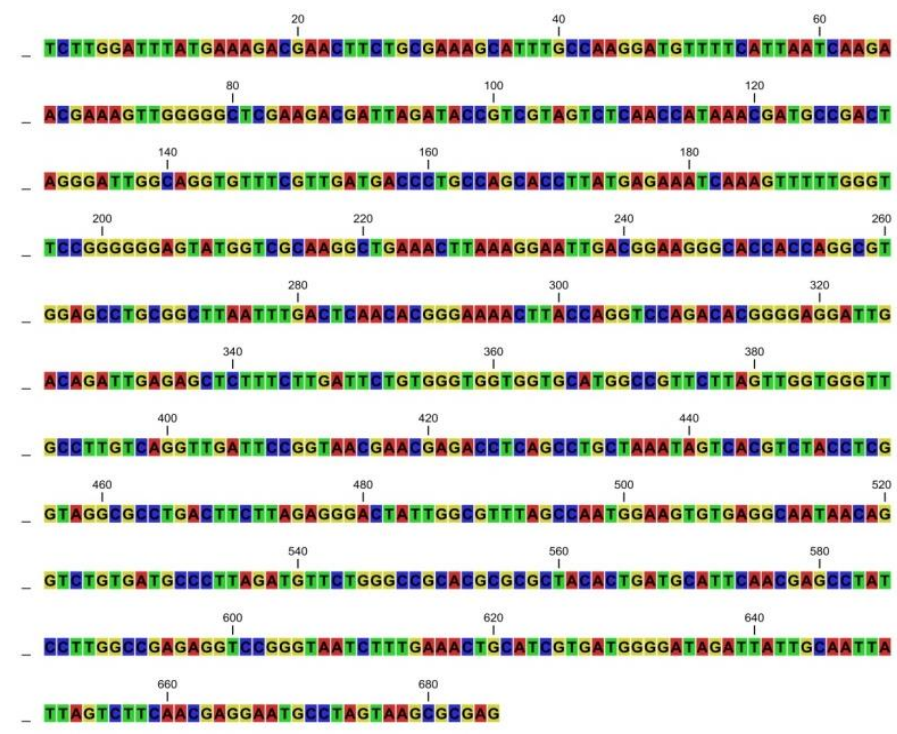

Fig. 1: Partial sequence of $18 \mathrm{~S}$ rRNA from the naturally isolated strain of $D$. salina deposited in NCBI under EF682841.2 accession number.

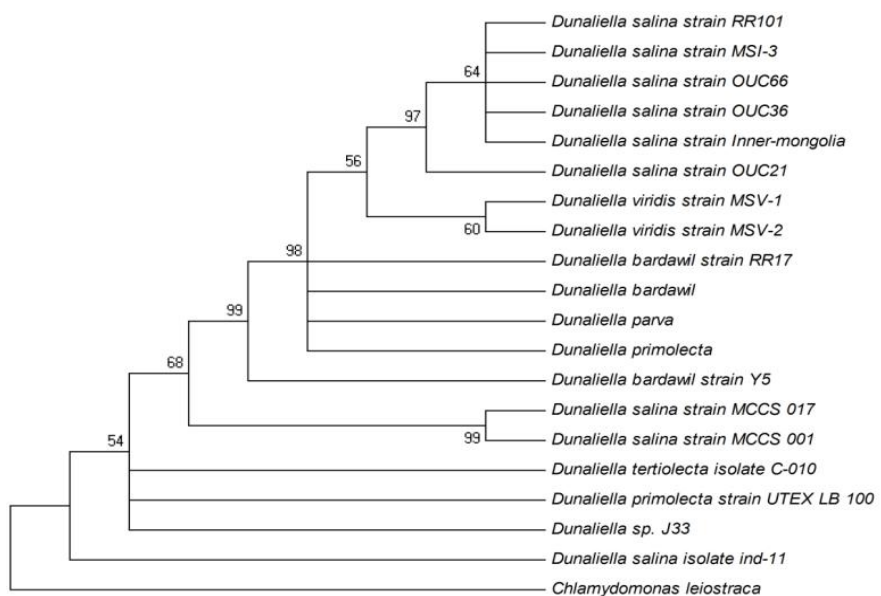

Fig. 2: Evolutionary relationships of 20 taxa (linearized). A phylogenic tree based on the entire 18S rRNA partial sequences of several species and strains of the genus D. salina and Chlamydomonas leiostraca (FR865590) asout-group was depicted by neighbor-joining analysis and maximum composite likelihood method. The indicator shows the D. salina strain MCC 001 .

PCR amplification of partial sequence of 18S rRNA was resulted in a single band on electrophoretic gel with $\sim 661 \mathrm{bp}$ in length. The result of PCR blasted with other sequenced microalgae in NCBI showed $99 \%$ homology to the $18 \mathrm{~S}$ small subunit rRNA of different strains of $D$. salina. A dendrogram based on the entire $18 \mathrm{~S}$ rRNA partial sequences of several species and strains of the genus D. salina and Chlamydomonas leiostraca (FR865590) asout-group was depicted by neighbor-joining analysis and maximum composite likelihood method (Fig. 2). The tree shows 
that the new isolated strain is part of a major clade containing several strains of $D$. salina and the closest relative of the isolated strain MCCS 001 was D.salina MCCS 017 with the accession number EU621363.1.

\section{Spectrophotometric assay}

Equation (1) shows that it is possible to give an estimation of the concentrations of $\beta$-carotene in $n$-hexane extract.

\section{Effect of hormone treatment on cell number}

The number of cells in all 5 groups $(5,10,15,20,25$ days of incubation) was determined within 25 days as shown in Table 1. All various concentrations of BAP, 2, 4-D, GA 3 , KN, SA and DAP seems to increase the cell number as compared to control group ( $p<0.05)$. Table 1 showed that both $\mathrm{KN}$ and IAA hormone had more effect on cell number than other hormones $(p<0.05)$ and also two times more than those in the control group. There were no significant differences between $\mathrm{KN}$ and IAA groups on increasing cell number. In contrast, BAP, GA $\mathrm{GAP}_{3}$ and SA hormones had less effect on rising cell number. The statistical analysis using the Tukey method and $95 \%$ confidence for growth rate showed that the maximum rate of growth was achieved on day 20 and then declined in day 25 .

\section{Effect of hormone treatment on total $\beta$-carotene content}

The $\beta$-carotene production of $D$. salina within 25 days was shown (Fig. 3). Concentrations of 0.01 to $1 \mu \mathrm{M}$ of these plant hormones favored growth of $D$. salina with significant difference as compared to control group.

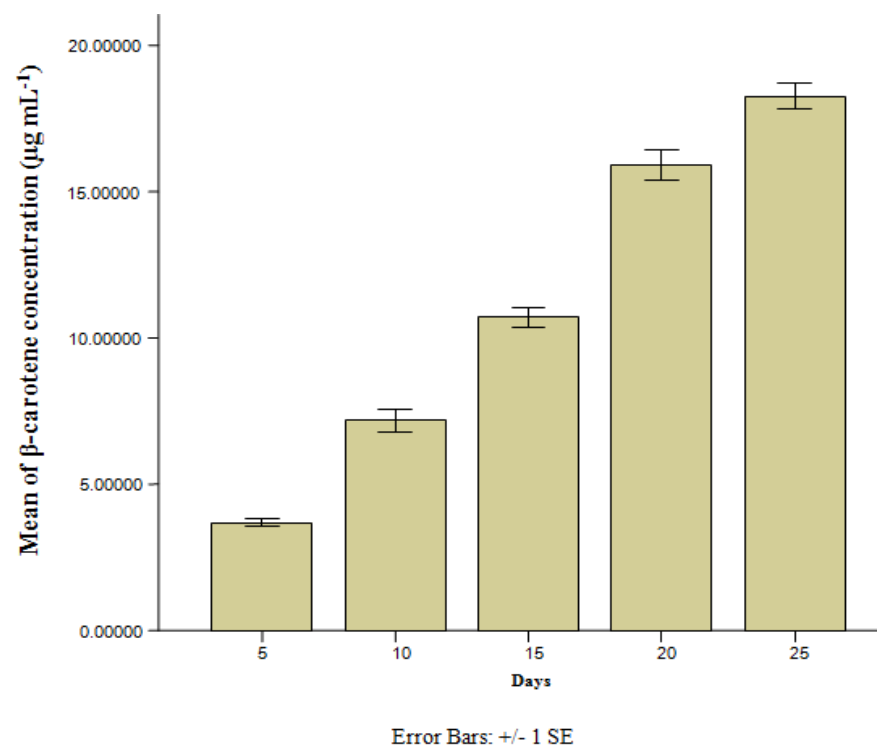

Fig. 3: The $\beta$-carotene production of $D$. salina within 25 days. The mean values of total $\beta$-carotene production in $D$. salina within 25 days of cultivation. The experiment was repeated three times, and the results presented are from a typical experiment. Bars represent the standard errors.

The effect of these plant hormone concentrations $(\mathrm{KN}$, $\mathrm{GA}_{3}$, BAP, IAA, 6- $\gamma, \gamma-$ DAP and SA group) on total content of $\beta$-carotene within 25 days was depicted in Table 2 and Fig. 4 . The results showed that the concentrations of total content of $\beta$ carotene in all days and in all groups were $(p<0.05)$ higher than that of the control group. KN and IAA had more effect on total content of $\beta$-carotene than other hormones $(p<0.05)$.

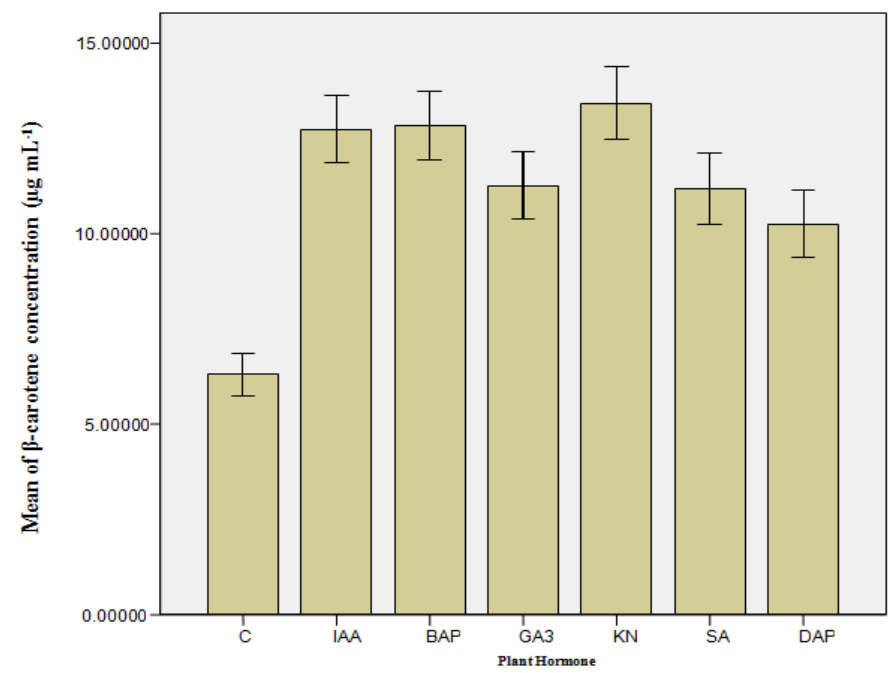

Fig. 4:The $\beta$-carotene production of $D$. salina in various hormone media (BAP, Benzyl amino purine; 2, 4-D, 2,4-Dichlorophenoxy acetic acid; $\mathrm{GA}_{3}$, Gibberellic acid; KN, Kinetin; SA, salicylic acid; DAP, $6 \gamma, \gamma$-Dimethylallyl aminopurine) and in normal media within 25 days. The experiment was repeated three times, and the results presented are from a typical experiment. Bars represent the standard errors.

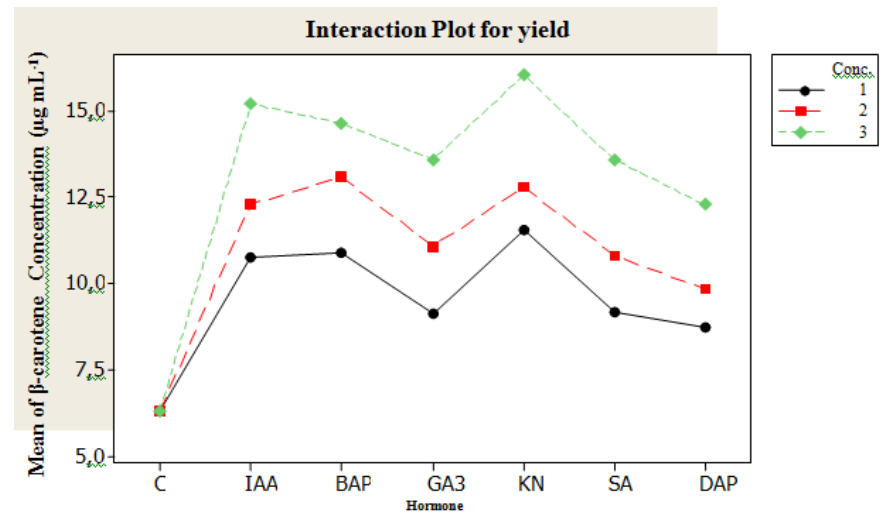

Fig. 5: Interaction plot of $\beta$-carotene production between hormones concentration. The experiment was repeated three times, and the results presented are from a typical experiment.

These amounts in $\mathrm{KN}$ groups were more than those in the control group and then IAA came after. The amount of total carotenoids observed on day 25 at hormone concentration of $1 \mu \mathrm{M}$ was the highest level of carotenoids compared to all other growth conditions. The interaction plot of $\beta$-carotene production between hormones different concentrations is shown in Fig. 5. The statistical analysis using the Tukey method and 95\% confidence for total content of beta-carotene showed that all hormones (at $1 \mu \mathrm{M})$ had the most effect on beta-carotene content and there was a significant difference in interaction between time (days) and concentration on beta-carotene production. However, higher plant hormone concentration increased the total carotenoid and the highest level of carotenoid content $\left(23.03 \mu \mathrm{g} \mathrm{mL}^{-1}\right)$ was gained at $1 \mu \mathrm{M} \mathrm{KN}$ hormone within 25 days. 
Table 1: Effect of IAA, BAP, $\mathrm{GA}_{3}, \mathrm{KN}, \mathrm{SA}$ and DAP on D. salina cell number.

\begin{tabular}{|c|c|c|c|c|c|c|c|}
\hline $\begin{array}{l}\text { Time } \\
\text { (Days) }\end{array}$ & $\begin{array}{c}\text { Hormone } \\
\text { concentration } \\
(\mu \mathrm{M})\end{array}$ & $\begin{array}{c}\text { Cell number } \\
\text { Mean } \pm \text { SD } \\
\text { (IAA") }\end{array}$ & $\begin{array}{c}\text { Cell number } \\
\text { Mean } \pm \text { SD } \\
(\text { BAP })\end{array}$ & $\begin{array}{c}\text { Cell number } \\
\text { Mean } \pm \text { SD } \\
\left(\mathbf{G A}_{3}\right)^{\prime} \mathbf{1}\end{array}$ & $\begin{array}{c}\text { Cell number } \\
\text { Mean } \pm \text { SD } \\
(\text { KN) }\end{array}$ & $\begin{array}{l}\text { Cell number } \\
\text { Mean } \pm \text { SD } \\
\text { (SA) }\end{array}$ & $\begin{array}{c}\text { Cell number } \\
\text { Mean } \pm \text { SD } \\
(\text { DAP) } 1\end{array}$ \\
\hline \multirow[t]{4}{*}{5} & $\mathrm{C}$ & $60.58 \pm 1.04$ & $60.58 \pm 1.04$ & $60.58 \pm 1.04$ & $60.58 \pm 1.04$ & $60.58 \pm 1.04$ & $60.58 \pm 1.04$ \\
\hline & 1 & $91.35 \pm 1.32$ & $85.3 \pm 0.4$ & $90 \pm 4.73$ & $88.75 \pm 1.01$ & $83.16 \pm 3.82$ & $85.25 \pm 1.32$ \\
\hline & 0.1 & $83.33 \pm 1.04$ & $78.83 \pm 3.55$ & $79.41 \pm 2.02$ & $85.16 \pm 2.55$ & $70.16 \pm 1.01$ & $74 \pm 0.09$ \\
\hline & 0.01 & $77.58 \pm 10.5$ & $67.83 \pm 5.1$ & $63.5 \pm 0.01$ & $80.16 \pm 6$ & $58.16 \pm 3.32$ & $71.25 \pm$ \\
\hline \multirow[t]{4}{*}{10} & $\mathrm{C}$ & $128.7 \pm 4.8$ & $128.7 \pm 4.8$ & $128.7 \pm 4.8$ & $128.7 \pm 4.8$ & $128.7 \pm 4.8$ & $128.7 \pm 4.8$ \\
\hline & 1 & $213.15 \pm 4.4$ & $206.83 \pm 6.8$ & $222.2 \pm 2.71$ & $223.5 \pm 3.55$ & $196.4 \pm 8.95$ & $204.6 \pm 4.41$ \\
\hline & 0.1 & $188.25 \pm 2.83$ & $186.2 \pm 1.07$ & $185.8 \pm 2.6$ & $194.3 \pm 3.61$ & $163.9 \pm 0.72$ & $17.08 \pm 3.32$ \\
\hline & 0.01 & $181.7 \pm 6.12$ & $164.3 \pm 6.3$ & $172.7 \pm 6.42$ & $196.3 \pm 4.4$ & $135.2 \pm 0.43$ & $156.1 \pm 3.57$ \\
\hline \multirow[t]{4}{*}{15} & $\mathrm{C}$ & $252.2 \pm 2.4$ & $252.2 \pm 2.4$ & $252.2 \pm 2.4$ & $252.2 \pm 2.4$ & $252.2 \pm 2.4$ & $252.2 \pm 2.4$ \\
\hline & 1 & $457.4 \pm 9.2$ & $365.9 \pm 4.91$ & $3.88 .9 \pm 1.89$ & $484 \pm 6.67$ & $274.3 \pm 7.63$ & $290.5 \pm 4.67$ \\
\hline & 0.1 & $369.6 \pm 6.73$ & $337.2 \pm 8.75$ & $338.5 \pm 4.75$ & $360.5 \pm 5.13$ & $328.6 \pm 5.04$ & $333.6 \pm 5.53$ \\
\hline & 0.01 & $330.5 \pm 5.44$ & $317.4 \pm 3.76$ & $324.4 \pm 0.26$ & $333.9 \pm 7.28$ & $304.3 \pm 9.7$ & $307.5 \pm 5.81$ \\
\hline \multirow[t]{4}{*}{20} & $\mathrm{C}$ & $430.4 \pm 3.76$ & $430.4 \pm 3.76$ & $430.4 \pm 3.76$ & $430.4 \pm 3.76$ & $430.4 \pm 3.76$ & $430.4 \pm 3.76$ \\
\hline & 1 & $649.91 \pm 4.75$ & $573.6 \pm 0.93$ & $592.2 \pm 1.32$ & $667 \pm 6.6$ & $541.2 \pm 5.5$ & $562.2 \pm 6.08$ \\
\hline & 0.1 & $466.9 \pm 2.87$ & $437 \pm 2.5$ & $454.2 \pm 4.25$ & $608.9 \pm 2.9$ & $431.3 \pm 4.1$ & $441.6 \pm 0.62$ \\
\hline & 0.01 & $481.3 \pm 1.02$ & $452.5 \pm 2.6$ & $461.7 \pm 2.6$ & $601.9 \pm 2.7$ & $440.5 \pm 1.39$ & $449 \pm 3.3$ \\
\hline \multirow[t]{4}{*}{25} & $\mathrm{C}$ & $377.6 \pm 1.56$ & $377.6 \pm 1.56$ & $377.6 \pm 1.56$ & $377.6 \pm 1.56$ & $377.6 \pm 1.56$ & $377.6 \pm 1.56$ \\
\hline & 1 & $502.3 \pm 1.84$ & $446.2 \pm 2.3$ & $596.6 \pm 3.4$ & $662.5 \pm 1.94$ & $538.9 \pm 4.3$ & $559.3 \pm 4.4$ \\
\hline & 0.1 & $523 \pm 1.84$ & $435.9 \pm 1.8$ & $456.8 \pm 3.7$ & $607 \pm 2.67$ & $427.1 \pm 0.49$ & $440.7 \pm 3.04$ \\
\hline & 0.01 & $479.3 \pm 1.15$ & $455.6 \pm 2.26$ & $465 \pm 1.4$ & $648 \pm 0.28$ & $442.3 \pm 4.47$ & $451.5 \pm 4.75$ \\
\hline
\end{tabular}

* BAP, Benzyl amino purine; 2, 4-D, 2,4-Dichlorophenoxy acetic acid; $\mathrm{GA}_{3}$, Gibberellic acid; KN, Kinetin; SA, salicylic acid; DAP, $6 \gamma, \gamma$-Dimethylallyl aminopurine. Each experiment was performed in triplicate and the mean values with standard deviations were presented.

Table 2: Effect of IAA, BAP, $\mathrm{GA}_{3}, \mathrm{KN}, \mathrm{SA}$ and DAP on $\beta$-carotene production in volume.

\begin{tabular}{|c|c|c|c|c|c|c|c|}
\hline $\begin{array}{l}\text { Time } \\
\text { (Days) }\end{array}$ & $\begin{array}{c}\text { Hormone } \\
\text { concentration } \\
(\mu \mathrm{M})\end{array}$ & $\begin{array}{c}\beta \text {-carotene Content } \\
\left(\mu \mathrm{g} \mathrm{mL} \mathbf{~}^{-1}\right) \\
\text { Mean } \pm \text { SD } \\
(\text { IAA })\end{array}$ & 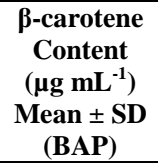 & $\begin{array}{c}\beta \text {-carotene Content } \\
\left(\mu \mathrm{g} \mathrm{mL} \mathbf{~}^{-1}\right) \\
\text { Mean } \pm \text { SD } \\
\left(\mathbf{G A}_{3}\right)\end{array}$ & $\begin{array}{c}\text {-carotene } \\
\text { Content } \\
\left(\mu \mathrm{g} \mathrm{mL} \mathbf{L}^{-1}\right) \\
\text { Mean } \pm \mathrm{SD} \\
(\mathrm{KN}) \\
\end{array}$ & 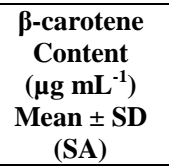 & $\begin{array}{c}\beta \text {-carotene } \\
\text { Content } \\
\left(\mu \mathrm{g} \mathrm{mL} \mathbf{~ m L}^{-1}\right) \\
\text { Mean } \pm \text { SD } \\
(\text { DAP })\end{array}$ \\
\hline \multirow[t]{4}{*}{5} & $\mathrm{C}$ & $1.52 \pm 0.040$ & $1.52 \pm 0.040$ & $1.52 \pm 0.040$ & $1.52 \pm 0.040$ & $1.52 \pm 0.040$ & $1.52 \pm 0.040$ \\
\hline & 0.01 & $4.08 \pm 0.005$ & $3.52 \pm 0.004$ & $3.1 \pm 0.008$ & $4.23 \pm 0.01$ & $2.81 \pm 0.003$ & $3.3 \pm 0.0085$ \\
\hline & 0.1 & $4.28 \pm 0.004$ & $4.032 \pm 0.003$ & $4.29 \pm 0.001$ & $4.36 \pm 0.003$ & $3.21 \pm 0.004$ & $3.44 \pm 0.001$ \\
\hline & 1 & $4.53 \pm 0.03$ & $4.89 \pm 0.017$ & $4.62 \pm 0.006$ & $4.83 \pm 0.028$ & $4.51 \pm 0.026$ & $4.17 \pm 0.0045$ \\
\hline \multirow[t]{4}{*}{10} & $\mathrm{C}$ & $2.77 \pm 0.11$ & $2.77 \pm 0.11$ & $2.77 \pm 0.11$ & $2.77 \pm 0.11$ & $2.77 \pm 0.11$ & $2.77 \pm 0.11$ \\
\hline & 0.01 & $7.73 \pm 0.008$ & $8.27 \pm 0.56$ & $4.29 \pm 0.005$ & $7.96 \pm 0.004$ & $3.33 \pm 0.0064$ & $3.37 \pm 0.065$ \\
\hline & 0.1 & $8.55 \pm 0.002$ & $9.01 \pm 0.024$ & $6.81 \pm 0.011$ & $8.96 \pm 0.001$ & $4.93 \pm 0.006$ & $5.58 \pm 0.0092$ \\
\hline & 1 & $12.34 \pm 0.005$ & $10.7 \pm 0.011$ & $9.93 \pm 0.004$ & $13.02 \pm 0.002$ & $8.87 \pm 0.0081$ & $6.8 \pm 0.0015$ \\
\hline \multirow[t]{4}{*}{15} & $\mathrm{C}$ & $6.67 \pm 0.036$ & $6.67 \pm 0.036$ & $6.67 \pm 0.036$ & $6.67 \pm 0.036$ & $6.67 \pm 0.036$ & $6.67 \pm 0.036$ \\
\hline & 0.01 & $11.23 \pm 0.005$ & $9.67 \pm 0.006$ & $7.82 \pm 0.005$ & $11.93 \pm 0.041$ & $8.75 \pm 0.0021$ & $7.36 \pm 0.0021$ \\
\hline & 0.1 & $12.02 \pm 0.013$ & $13.13 \pm 0.062$ & $9.14 \pm 0.011$ & $12.02 \pm 0.011$ & $11.54 \pm 0.002$ & $13.1 \pm 0.0081$ \\
\hline & 1 & $13.91 \pm 0.045$ & $14.81 \pm 0.035$ & $13.65 \pm 0.004$ & $13.91 \pm 0.003$ & $14.2 \pm 0.0037$ & $14.8 \pm 0.0049$ \\
\hline \multirow[t]{4}{*}{20} & $\mathrm{C}$ & $8.64 \pm 0.03$ & $8.64 \pm 0.03$ & $8.64 \pm 0.03$ & $8.64 \pm 0.03$ & $8.64 \pm 0.03$ & $8.64 \pm 0.03$ \\
\hline & 0.01 & $15.17 \pm 0.066$ & $15.49 \pm 0.026$ & $12.79 \pm 0.005$ & $15.17 \pm 0.004$ & $14.75 \pm 0.016$ & $15.4 \pm 0.0028$ \\
\hline & 0.1 & $17.99 \pm 0.026$ & $18.84 \pm 0.026$ & $15.6 \pm 0.0011$ & $17.99 \pm 0.001$ & $15.54 \pm 0.002$ & $18.8 \pm 0.0089$ \\
\hline & 1 & $22.02 \pm 0.019$ & $21.36 \pm 0.041$ & $18.45 \pm 0.004$ & $22.02 \pm 0.002$ & $19.2 \pm 0.017$ & $21.3 \pm 0.0051$ \\
\hline \multirow[t]{4}{*}{25} & $\mathrm{C}$ & $11.03 \pm 0.014$ & $11.03 \pm 0.014$ & $11.03 \pm 0.014$ & $11.03 \pm 0.014$ & $11.03 \pm 0.014$ & $11.03 \pm 0.014$ \\
\hline & 0.01 & $16.07 \pm 0.13$ & $17.06 \pm 0.002$ & $16.83 \pm 0.058$ & $16.07 \pm 0.016$ & $16.88 \pm 0.061$ & $17.06 \pm 0.047$ \\
\hline & 0.1 & $18.22 \pm 0.014$ & $20.1 \pm 0.013$ & $19.85 \pm 0.014$ & $18.22 \pm 0.004$ & $18.1 \pm 0.0067$ & $20.1 \pm 0.049$ \\
\hline & 1 & $23.03 \pm 0.021$ & $22.35 \pm 0.037$ & $20.1 \pm 0.018$ & $23.03 \pm 0.008$ & $21.9 \pm 0.0031$ & $22.35 \pm 0.064$ \\
\hline
\end{tabular}

* BAP, Benzyl amino purine; 2, 4-D, 2,4-Dichlorophenoxy acetic acid; $\mathrm{GA}_{3}$, Gibberellic acid; KN, Kinetin; SA, salicylic acid; DAP, $6 \gamma, \gamma$-Dimethylallyl aminopurine. Each experiment was performed in triplicate and the mean values with standard deviations were presented.

\section{Effect of hormonal treatment on $\beta$-carotene production per cell}

$\beta$-carotene content per cell was measured by dividing total content of $\beta$-Carotene on cell number in concentrations of control (o) to $1 \mu \mathrm{M}$ of these plant hormones. The effect of these plant hormone concentrations (KN, GA 3 , BAP, IAA, 6- $\gamma, \gamma$ - DAP and SA group) on $\beta$-carotene content per cell within 25 days was depicted in Table 3. The results showed that the concentrations of $\beta$-carotene content per cell in all days and in all groups were $(p<$ 0.05 ) higher than that of the control group. SA in concentration of $0.01 \mu \mathrm{M}$ has more effect on $\beta$-carotene content per cell than other hormones $(p<0.05) . \mathrm{KN}$ in concentration of $1 \mu \mathrm{M}$ has less effect on $\beta$-carotene content per cell than other hormones $(p<0.05)$ on day 25 . 
Table 3: Effect of IAA, BAP, GA $\mathrm{GA}_{3}, \mathrm{KN}, \mathrm{SA}$ and DAP on $\beta$-carotene production per cell.

\begin{tabular}{|c|c|c|c|c|c|c|c|}
\hline $\begin{array}{c}\text { Time } \\
\text { (Days) }\end{array}$ & $\begin{array}{c}\text { Hormone } \\
\text { concentration } \\
(\mu \mathrm{M})\end{array}$ & $\begin{array}{c}\beta \text {-carotene Content } \\
\text { per cell } \\
\left(\text { pg mL } \mathbf{~}^{-1}\right) \\
\text { Mean } \pm \text { SD } \\
\text { (IAA) }\end{array}$ & $\begin{array}{c}\beta \text {-carotene } \\
\text { Content } \\
\text { per cell } \\
\left(\text { pg mL } \mathbf{m}^{-1}\right) \\
\text { Mean } \pm \text { SD } \\
(\text { BAP })\end{array}$ & $\begin{array}{c}\beta \text {-carotene } \\
\text { Content } \\
\text { per cell } \\
\left(\text { pg mL } \mathbf{m L}^{-1}\right) \\
\text { Mean } \pm \text { SD } \\
\left(\mathbf{G A}_{3}\right)\end{array}$ & $\begin{array}{c}\beta \text {-carotene } \\
\text { Content } \\
\text { per cell } \\
\left(\text { pg mL } \mathbf{m L}^{-1}\right) \\
\text { Mean } \pm \text { SD } \\
(\mathrm{KN})\end{array}$ & $\begin{array}{c}\beta \text {-carotene } \\
\text { Content } \\
\text { per cell } \\
\left(\text { pg mL } \mathbf{m L}^{-1}\right) \\
\text { Mean } \pm \text { SD } \\
(\mathrm{SA})\end{array}$ & $\begin{array}{c}\beta \text {-carotene } \\
\text { Content } \\
\text { per cell } \\
\left(\text { pg mL } \mathbf{m L}^{-1}\right) \\
\text { Mean } \pm \text { SD } \\
(\text { DAP })\end{array}$ \\
\hline \multirow[t]{4}{*}{5} & $\mathrm{C}(0)$ & $0.021 \pm 0.53$ & $0.021 \pm 0.53$ & $0.021 \pm 0.53$ & $0.021 \pm 0.53$ & $0.021 \pm 0.53$ & $0.021 \pm 0.53$ \\
\hline & 0.01 & $0.0516 \pm 0.054$ & $0.051 \pm 0.19$ & $0.068 \pm 0.65$ & $0.051 \pm 0.004$ & $0.06 \pm 0.0087$ & $0.033 \pm 0.0091$ \\
\hline & 0.1 & $0.052 \pm 0.6$ & $0.051 \pm 0.38$ & $0.06 \pm 0.76$ & $0.05 \pm 0.003$ & $0.057 \pm 0.031$ & $0.044 \pm 0.058$ \\
\hline & 1 & $0.0509 \pm 0.55$ & $0.049 \pm 0.19$ & $0.035 \pm 0.965$ & $0.046 \pm 0.009$ & $0.077 \pm 0.009$ & $0.048 \pm 0.076$ \\
\hline \multirow[t]{4}{*}{10} & $\mathrm{C}(0)$ & $0.022 \pm 0.9$ & $0.022 \pm 0.9$ & $0.022 \pm 0.9$ & $0.022 \pm 0.9$ & $0.022 \pm 0.9$ & $0.022 \pm 0.9$ \\
\hline & 0.01 & $0.045 \pm 0.043$ & $0.045 \pm 1.24$ & $0.063 \pm 0.09$ & $0.057 \pm 0.0067$ & $0.051 \pm 0.003$ & $0.017 \pm 0.106$ \\
\hline & 0.1 & $0.045 \pm 0.976$ & $0.044 \pm 0.86$ & $0.04 \pm 0.030$ & $0.04 \pm 0.076$ & $0.048 \pm 0.006$ & $0.026 \pm 0.009$ \\
\hline & 1 & $0.0596 \pm 0.47$ & $0.049 \pm 0.047$ & $0.023 \pm 0.765$ & $0.055 \pm 0.032$ & $0.064 \pm 0.079$ & $0.042 \pm 0.032$ \\
\hline \multirow[t]{4}{*}{15} & $\mathrm{C}(0)$ & $0.03 \pm 0.45$ & $0.03 \pm 0.45$ & $0.03 \pm 0.45$ & $0.03 \pm 0.45$ & $0.03 \pm 0.45$ & $0.03 \pm 0.45$ \\
\hline & 0.01 & $0.036 \pm .005$ & $0.0311 \pm 0.52$ & $0.042 \pm 0.12$ & $0.033 \pm 0.18$ & $0.03 \pm 0.54$ & $0.026 \pm 0.072$ \\
\hline & 0.1 & $0.0314 \pm 0.32$ & $0.026 \pm 0.95$ & $0.025 \pm 0.099$ & $0.032 \pm 0.61$ & $0.037 \pm 0.070$ & $0.031 \pm 0.051$ \\
\hline & 1 & $0.031 \pm 0.86$ & $0.033 \pm 0.29$ & $0.021 \pm 0.154$ & $0.036 \pm 0.006$ & $0.047 \pm 0.180$ & $0.035 \pm 0.007$ \\
\hline \multirow[t]{4}{*}{20} & $\mathrm{C}(0)$ & $0.02 \pm 0.76$ & $0.02 \pm 0.76$ & $0.02 \pm 0.76$ & $0.02 \pm 0.76$ & $0.02 \pm 0.76$ & $0.02 \pm 0.76$ \\
\hline & 0.01 & $0.025 \pm 1.1$ & $0.028 \pm 0.62$ & $0.023 \pm 0.34$ & $0.025 \pm 0.43$ & $0.027 \pm 0.0029$ & $0.033 \pm 0.006$ \\
\hline & 0.1 & $0.028 \pm 0.23$ & $0.032 \pm 0.006$ & $0.024 \pm 0.611$ & $0.028 \pm 0.095$ & $0.032 \pm 0.009$ & $0.029 \pm 0.602$ \\
\hline & 1 & $0.0326 \pm 0.005$ & $0.031 \pm 0.54$ & $0.018 \pm 0.054$ & $0.032 \pm 0.614$ & $0.038 \pm 0.112$ & $0.028 \pm 0.009$ \\
\hline \multirow[t]{4}{*}{25} & $\mathrm{C}(0)$ & $0.023 \pm 1.01$ & $0.023 \pm 1.01$ & $0.023 \pm 1.01$ & $0.023 \pm 1.01$ & $0.023 \pm 1.01$ & $0.023 \pm 1.01$ \\
\hline & 0.01 & $0.025 \pm 0.12$ & $0.028 \pm 0.34$ & $0.032 \pm 0.65$ & $0.026 \pm 0.025$ & $0.028 \pm 0.008$ & $0.033 \pm 0.001$ \\
\hline & 0.1 & $0.027 \pm .025$ & $0.031 \pm 0.45$ & $0.029 \pm 0.901$ & $0.027 \pm 0.0761$ & $0.033 \pm 0.094$ & $0.031 \pm 0.008$ \\
\hline & 1 & $0.0322 \pm .054$ & $0.031 \pm 0.49$ & $0.023 \pm 0.701$ & $0.031 \pm 0.349$ & $0.037 \pm 0.101$ & $0.031 \pm 0.104$ \\
\hline
\end{tabular}

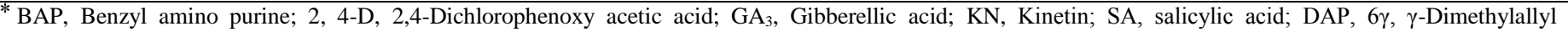
aminopurine. Each experiment was performed in triplicate and the mean values with standard deviations were presented.

\section{DISCUSSION}

The amount of plant hormones has been identified in numerous higher order plants, and these diverse forms have been associated to different growth and developmental processes. As to our best knowledge, this study investigates the effect of plant growth regulators on the growth and production of $\beta$-carotene in D. salina. The studied microalga was cultured in $250 \mathrm{~mL}$ flasks with $12 \%$ salinity, because the optimum salinity for $\beta$-carotene production is $12 \% \mathrm{NaCl}$. In this study, six plant hormones were used: kinetin $(\mathrm{KN})$, indole-3-acetic acid (IAA), benzyl adenine purine (BAP), and gibberellic acid $\left(\mathrm{GA}_{3}\right), 6 \gamma, \gamma$-Dimethylallyl amino purine (DAP), salicylic acid (SA). According to the results, $\mathrm{KN}$ and IAA had the most effect on cell growth. The cell number in the media with $\mathrm{KN}$ and IAA were about two times more than that in control groups (Table 3). DAP and SA had less effect on cell number of $D$. salina in the culture media than $\mathrm{KN}$ and IAA, but there was a significant difference between them and the control groups. These hormones may affect the number of cells or growth rate of $D$. salina through these mechanisms. The results illustrated that these hormones have positive effects on cell number, which are in accordance with those reported by Liangxia who studied the effect of six hormones on the growth rate of D. salina (Liangxia, 2007). Activation of downstream genes of hormone-regulated plant reaction depends on understanding plant hormones mechanisms which have been discussed for auxin, GA, cytokinins, ABA, ethylene, BR and JA. However, receptors for these hormones have been verified and different interesting biochemical natures of these hormone receptors along with some important downstream signaling parts of the receptors are still necessary to be discovered. More receptors for these hormones may have been known in the near future. However, recent studies indicated that the Auxin- Binding Protein 1 (ABP1) perceived auxin signal to mediate TIR1-independent auxin responses (Shan et al., 2012).Very few reports are collected about the physiological role of cytokines in the growth and development of microalgae. In most reports, the role of exogenous cytokines instigates growth and cell division and increases dry weight, protein contents, and photosynthetic pigments. The results of this research are in contrary with Ördög et al. who reported that exogenous application of cytokines had little or no effect on micro algal cultures (Ördög et al., 2004). By using hormones, more biomass will be obtained in a shorter period, which can be useful in producing tablets or capsules of D. salina or in production of single cell proteins. DAP had more effect on total content of $\beta$ carotene than other hormones $(p<0.05)$. The influence of $\mathrm{KN}$ (also IAA and to some extent BAP) on total $\beta$-carotene production of $D$. salina is really intriguing, because more biomass and more total content of $\beta$-carotene can be obtained, which is the purpose of many studies in a shorter time for $\beta$-carotene production. According to results, it seems that increasing in carotenoid content is dependent upon increasing the cell number. As mentioned above, carotenoid content in starvation and stress condition is increased. Arash Rad et al. have shown that growth rate has affected the carotenoid production, when growth rate reduces, the carotenogenesis rate increases (Arash Rad et al., 2011). Therefore, to correct investigation of hormone effect, it was needed to measure cell growth and $\beta$-carotene production per cell. In this experiment measurement of $\beta$-carotene production per cell of $D$. salina was carried out with dividing total content of $\beta$-carotene on 
cell number for all samples. Result from measuring $\beta$-carotene production per cell of $D$. salina showed that $\beta$-carotene content (per cell) of Dunaliella sp. was decreased for all plant hormone compared whit control (media without plant hormone) during 25 days. These Result showed that total carotenoid content increase in alga under the influence of $\mathrm{KN}$ correlated with their cell proliferation. As shown in Table 1 and 3, plant hormones had stimulatory effects on algal growth, but they had reducing effect on carotenoid production. A simple and available spectrophotometric method has been developed in this study for quantitation of $\beta$-carotene. A notable advantage of this method over the previously reported spectrophotometric methods for $\beta$ carotene quantification was its considerable longer run times as well as availability and popularity, both of which being of great impact in practice, particularly when a high number of samples are to be analyzed. This method can provide a simple and easy way to assay $\beta$-carotene in such sources like food, drugs, etc. It was recently announced by the National Cancer Institute that $\beta$ carotene has anti carcinogenic effects. Other studies have found that $\beta$-carotene is effective in controlling cholesterol and in reducing the risk of heart disease. These new findings make $\beta$ carotene much more valuable and are likely to increase the demand for the product. Being fat soluble, the natural $\beta$-carotene is a much superior anti carcinogenic and anti-heart disease agent. Thus the new findings of these desirable medicinal properties are likely to increase even more the demand and desirability of natural $\beta$-carotene.The main challenges facing the algal $\beta$-carotene producer are the need to continue to improve the algal culture process. Therefore, there is a need for increasing the $\beta$-carotene productivity by escalating the growth rate and reliability and also by improving the $\beta$-carotene content of the cells. Thus, this requires improvements in the design of the production plants, a better understanding of Dunaliella physiology and finding new algal strains, which can be obtained by mutagenesis procedures and genetic engineering techniques (Borowitzka, 1999).

\section{ACKNOWLEDGEMENTS}

This work was supported by the Research Council of Shiraz University of Medical Sciences, Shiraz, Iran.

\section{REFERENCES}

Arash Rad F, Aksoz N, Hejazi MA. Effect of salinity on cell growth and $\beta$-carotene production in Dunaliella sp. isolates from Urmia Lake in northwest of Iran. Afr. J. Biotechnol., 2011; 10(12), 2282-9.

Ben-Amotz A, Lers A, Avron M. Stereoisomers of betacarotene and phytoene in the alga Dunaliella bardawil. Plant Physiol., 1988;86(4):1286-91.

Borowitzka MA. Commercial production of microalgae: Ponds, tanks, tubes and fermenters. J Biotechnol., 1999;70(1-3):313-21.

Cardoso LC, Serrano CM, Rodríguez MR, de la Ossa EJM, Lubián LM. Extraction of carotenoids and fatty acids from microalgae using supercritical technology. Am. J. Anal. Chem., 2012;3(12A):877-83.

Chen H, Jiang J-G, Wu G-H. Effects of salinity changes on the growth of Dunaliella salina and its isozyme activities of glycerol-3phosphate dehydrogenase. J. Agr. Food Chem., 2009;57(14):6178-82.
Cowan AK, Rose PD. Abscisic acid metabolism in salt-stressed cells of Dunaliella salina: Possible interrelationship with $\beta$-carotene accumulation. Plant Physiol., 1991;97(2):798-803.

Dipak P, Lele S. Carotenoid production from microalga, Dunaliella salina. Ind. J. Biotechnol., 2005;4(8):476-83.

Eijckelhoff C, Dekker J. A routine method to determine the chlorophyll $a$, pheophytin $a$ and $\beta$-carotene contents of isolated photosystem II reaction center complexes. Photosynth. Res., 1997;52(1):69-73.

Emeish S. Production of natural $\beta$-carotene from Dunaliella living in the Dead Sea. Jordan J. Earth Env. Sci., 2012;4:23-7.

Felsenstein J. Confidence limits on phylogenies: An approach using the bootstrap. Evolution., 1985:783-91.

Gaspar T, Kevers C, Penel C, Greppin H, Reid D, Thorpe T. Plant hormones and plant growth regulators in plant tissue culture. In Vitro Cell. Dev. Biol.-Plant., 1996;32(4):272-89.

Ghasemi Y, Rasoul-Amini S, Morowvat MH. Algae for the production of SCP. In: Liong MT, editor. Bioprocess Sciences and Technology: Nova Science Publishers, Inc.; 2011a. p. 163-84.

Ghasemi Y, Rasoul-Amini S, Kazemi A, Zarrinic G, Morowvat $\mathrm{MH}$, Kargar M. Isolation and characterization of some moderately halophilic bacteria with lipase activity. Mikrobiologiia., 2011b;80(4):47781.

Ghasemi Y, Rasoul-Amini S, Morowvat MH, Azam SBM, Shokravi S, Mohagheghzadeh A, et al. Bioconversion of hydrocortisone by unicellular microalga Oocystis pusilla. Biotechnology., 2008;7(2):2938 .

Ghasemi Y, Rasoul-Amini S, Naseri A, Montazeri-Najafabady N, Mobasher M, Dabbagh F. Microalgae biofuel potentials (Review). Appl. Biochem. Microbiol., 2012;48(2):126-44.

Gross D. Growth regulating substances of plant origin. Phytochemistry., 1975;14(10):2105-12.

Guedes AC, Amaro HM, Malcata FX. Microalgae as sources of carotenoids. Mar. Drugs., 2011;9(4):625-44.

Hejazi MA, Holwerda E, Wijffels RH. Milking microalga Dunaliella salina for $\beta$-carotene production in two-phase bioreactors. Biotechnol. Bioeng., 2004;85(5):475-81.

Lamers PP, Janssen M, De Vos RCH, Bino RJ, Wijffels RH. Exploring and exploiting carotenoid accumulation in Dunaliella salina for cell-factory applications. Trends Biotechnol., 2008;26(11):631-8.

Liangxia Z. Influence of six kinds of hormones on growth of Dunaliella salina. J. Anhui Agr. Sci., 2007;35(16):4764.

Ördög V, Stirk WA, Van Staden J, Novák O, Strnad M. Endogenous cytokinins in three genera of microalgae from the Chlorophyta. J. Phycol., 2004;40(1):88-95.

Polle JE, Struwe L, Jin E. Identification and characterization of a new strain of the unicellular green alga Dunaliella salina (Teod.) from Korea. J Microbiol. Biotechnol., 2008;18(5):821-7.

Powtongsook S, Kittakoop P, Menasveta P, Wisessang S. Isolation and characterization of Dunaliella salina from Thailand. J. Appl. Phycol., 1995;7(1):75-6.

Rasoul-Amini S, Mousavi P, Montazeri-Najafabady N, Mobasher MA, Mousavi SB, Vosough F, et al. Biodiesel properties of native strain of Dunaliella salina. Int. J. Renew. Energ. Res., 2014a;4(1):39-41.

Rasoul-Amini S, Montazeri-Najafabady N, Shaker S, Safari A, Kazemi A, Mousavi P, et al. Removal of nitrogen and phosphorus from wastewater using microalgae free cells in bath culture system. Biocatal. Agric. Biotechnol., 2014b;3(2):126-31.

Sabovljević A, Sabovljević M, Grubišić D. Gibberellin influence on the morphogenesis of the moss Bryum argenteum Hedw. In in vitro conditions. Arch. Biol. Sci., 2010;62(2):373-80.

Saitou N, Nei M. The neighbor-joining method: A new method for reconstructing phylogenetic trees. Mol. Biol. Evol., 1987;4(4):406-25.

Salguero A, de la Morena B, Vigara J, Vega JM, Vilchez C, Leon R. Carotenoids as protective response against oxidative damage in Dunaliella bardawil. Biomol.Eng., 2003;20(4-6):249-53. 
Shan X, Yan J, Xie D. Comparison of phytohormone signaling mechanisms. Curr. Opin. Plant Biol., 2012;15(1):84-91.

Tamura K, Dudley J, Nei M, Kumar S. MEGA4: Molecular evolutionary genetics analysis (MEGA) software version 4.0. Mol. Biol. Evol., 2007;24(8):1596-9.

Tamura K, Nei M, Kumar S. Prospects for inferring very large phylogenies by using the neighbor-joining method. Proc. Natl. Acad. Sci. USA., 2004;101(30):11030-5.

Tarakhovskaya E, Maslov YI, Shishova M. Phytohormones in algae. Russ. J. Plant Physiol., 2007;54(2):163-70.

Venkatesan S, Senthil M, Senthil C, Bashkar S, Rengasamy R. Culturing marine green microalgae Dunaliella salina Teod. and Dunaliella tertiolecta Masjuk in Dewalne's medium for valuable feeds stock. J. Modern Biotechnol., 2013;2(2):40-5.

Yazdi MT, Ghasemi Y, Ghasemian A, Shokravi S, Niknahad H, Amini $\mathrm{M}$, et al. Bioconversion of hydrocortisone by cyanobacterium
Fischerella ambigua PTCC 1635. World J. Microbiol. Biotechnol., 2005;21(6-7):811-4.

Ye Z-W, Jiang J-G, Wu G-H. Biosynthesis and regulation of carotenoids in Dunaliella: progresses and prospects. Biotechnol. Adv., 2008; 26(4):352-60.

\section{How to cite this article:}

Mousavi P, Morowvat MH, Montazeri-Najafabady N, Abolhassanzadeh Z, Mohagheghzadeh A, Hamidi M, Niazi A, Ghasemi Y. Investigating the effects of phytohormones on growth and $\beta$-carotene production in a naturally isolates stain of Dunaliella salina. J App Pharm Sci, 2016; 6 (08): 164-171. 